\title{
BENTUK OPTIMALISASI TEKNOLOGI INFORMASI DALAM MENDUKUNG E-COMMERCE USAHA KECIL DAN MENENGAH
}

\author{
Noor Hadi \\ Program Studi Akuntansi Syari'ah STAIN Kudus \\ nh_ok@yahoo.co.id
}

\begin{abstract}
This research are intended to explore the utilization of information technology for small and medium enterprises (SMEs)to develop market share in the form of e-marketing. The results showed that SMEs in the city of Semarang has utilized information technology, from the simplest to the advanced. Hand Phone and computer are a tool that used it, although for computers not all SMEs have been using it. The form of communications media used by SMEs such as: SMS, whatshap, e-mail, website, blog, istagram, blackbarry, line, and the like. The acceptable outcomes of SMEs when they use technology are in addition to encouraging increased sales, as well as obtaining convenience when communicating with customers, ordering, marketing products, identifying customer needs, identify supplier needs, consumer surveys and the like.
\end{abstract}

Keywords: Information Technology, Small and Medium Enterprises, technology adoption, e-marketing or e-commerce.

\section{A. Pendahuluan}

Jika di tracing dalam perjalanan perekonomian Indonesia, struktur bisnis Indonesia tergolong unik. Keunikan perekonomian Indonesia ditunjukkan dengan posisi dan komposisi usaha kecil dan menengah (UKM) dalam percaturan bisnis nasional. Usaha kecil dan menengah (UKM)memiliki kontribuai besar dan menjadi kelompok usaha penyangga ekonomi masyarakat. Namun demikian, eksistensi UKM belum memperoleh porsi seimbang dalam kebijakan nasional. Keberpihakan terhadap UKM masih tegolong kecil dan 
belum menjadikannya memiliki kemampuan bersaing secara global sebagaimana UKM-UKM dibeberapa negara.

Banyak persoalan dan keterbatasan yang dihadapi oleh UMK, mulai dari akses modal, bankcable, akses teknologi, sumberdaya manusia, sampai pada akses pasar. Keuntungan yang masih melekat adalah sebatas keungguan karakter produk yang bermuatan lokal tinggi, serta kedekatannya dengan konsumen sehingga memperoleh customers spreed yang lebih dulu dan besar, akhirnya UKM masih dapat tumbuh dan survive (Hadi Nor, 2015). Dari situ, UKM tidak mudah goyah, kendatipun akses pasar ke luar negeri sangat terbatas.

Menurut hasil penelitian The Hongkong and Shanghai Banking Corporation (HSBC)2007 menunjukkan UKM di Indonesia memiliki kekuatan ekonomi yang bagus jika cara pemberdayaannya tepat. Jumlah UKM di Indonesia yang sekitar $64 \%$ merupakan modal ekonomi besar karena distribusi pelaku bisnis bersifat merata, terlebih sekitar $44 \%$ pengusaha UKM di Indonesia berkeinginan kuat untuk menaikkan investasi serta siap menambah menambah tenaga kerja (Rahmana, 2009). Artinya, ketepatan kebijakan penguatan pertumbunhan UKM di Indonesia akan memicu Indonesia menjadi negara ekonomi kuat baru dibandingkan dengan negara-negara sekitarnya.

Potensi besar UKM di Indonesia tersebut tidak ada maknanya apabila sentuhan setimulus kebijakan tidak berpihak secara optimal. Patut disadari bahwa business entreprise sekelas small business seperti ini memiliki banyak sekali keterbatasan yang terkadang melemahkan posisinya. Hasil penelitian HadiNor, dkk (2005) menunjukkan bahwa pelaku bisnis UKM disamping memiliki kelebihan juga banyak kelemahan yang sering menggiring mereka harus menutuip usaha, seperti: (1) keterbatasan akses pasar; (2) keterbatasan permodal dan sumber permodalan; (3) keterbatasan standarisasi produk; (4) sulit akses hak patent dan sejenisnya; (5) keterbatasan manajerial. Diantara keterbatasan UKM tersebut, yang sering mengganggu pengembangan UKM adalah keterbatasan modal dan akses modal, serta ruang kompetisi pasar sehingga market share yang dimiliki pada sangat terbatas. 
Munculnya tehnologi informasi yang berujung pada berkembangan e-commerce seharusnya dapat dijadikan ruang pasar baru bagi UKM. Hal itu karena, teknologi informasi merupakan jalan tol pemasaran yang berbiaya murah, tidak banyak membutuhkan mobilisasi sumberdaya pemasaran, berkecepatan tinggi, dan keakuratannya andal. Dengan webside yang dimiliki, pelaku bisnis dapat mempromosikan, memasarkan, dan menjual produk tanpa harus membuat brosur secara fisik, mengangkat sales promotion, membayar iklan besar-besaran lewat media massa, yang semua itu membutuhkan biaya promosi besar. Teknologi informasi dapat dijadikan alternatif pemasaran baru lewat e-marketing untuk memperluas market share sampai jangkauan yang lebih luas, termasuk pasar luar negeri.

Meskipun demikian, pemanfatan teknologi informasi (IT) belum ditangkap secara maksimal para pelaku small business interprise. Kendatipun sudah banyak UKM yang telah memanfaatkan teknologi informasi dalam memasarkan dan mempromosikan produk, namun belum sebanding dengan jumlah UKM yang ada. Banyak kendala pada UKM dalam akses terhadap teknologi informasi, seperti: (1) kendala budaya yang kurang terbuka terhadap teknologi; (2) masih terbatas konsumen yangmemafaatkan berbelajan berbasis on-line; (3) masih terbatas pemahaman peran strategis teknologi informasi untuk pemasaran, dan (4) rendahnya integritas dan trush dalam penjualan dan pembelian berbasis internet (Hawk, 2004; Paul, 2002; Wahid, 2004).

Penelitian ini dimaksudkan untuk meng-eksplourer pemanfaatan atau optimalisasi teknologi informasi dalam peningkakan e-commerce di UKM, serta efektifitasnya untuk meningkatkan penjualan UKM di Kota Semarang.

\section{B. Pembahasan}

\section{Deskripsi UKM}

Penelitian dilakukan di Kota Semarang yang melibatkan 100 UKM. Kota Semarang menjadi target (objek) penelitian didasarkan pertimbangan sebagai ibu Kota Propopinsi, yang mana, UKM menjadi jenis usaha yang peka terhadap penyerapan tenaga kerja, 
memiliki kontribusi besar terhadap ekonomi masyarakat sekitar, signifikan menyokong PDRB, serta memiliki kerentanan terhadap problem penganagguran.

Dari 100 UKM yang menjadi target penelitian, dikelompokkan menurut pengalaman UKM yang dilihat dari aspek umur UKM, dan industri UKM. Adapun deskripsi UKM di Kota Semarang yang menjadi target peneltian dijelaskan sebagai berikut:

Gambar 1. Umur UKM

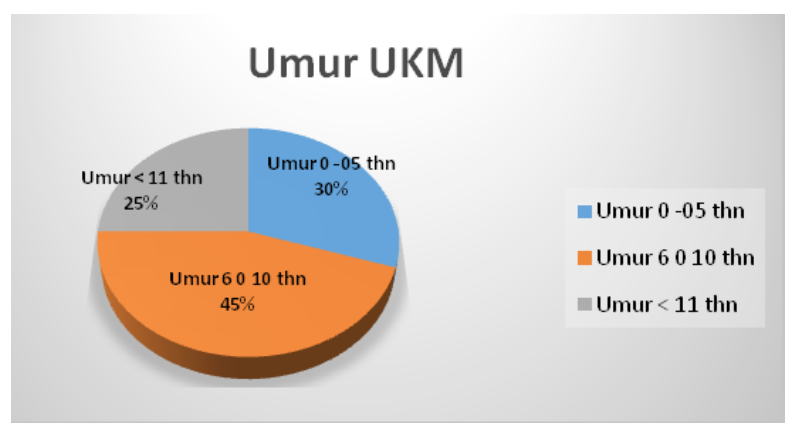

Sumber: Data Primer Diolah

Diagram sebagaimana tersebut diatas menunjukkan bahwa jumlah UKM yang dijadikan objek penelitian sebanyak 100 UKM, yang meliputi umur UKM antara $0 \mathrm{~s} / \mathrm{d} 5$ tahun sebanyak 30 UKM (30\%), umur $6 \mathrm{~s} / \mathrm{d}$ 10tahun sebanyak 45 UKM (45\%), dan umur UKM diatas 11 tahun sebanyak 25 UKM (25\%).

Sementara jika dilihat dari karakteristik usaha dan bidang usaha yang digeluti para UKM yang menjadi target penellitian, dijelaskan sebagai berikut:

Tabel. 1 Deskripsi Usaha UKM

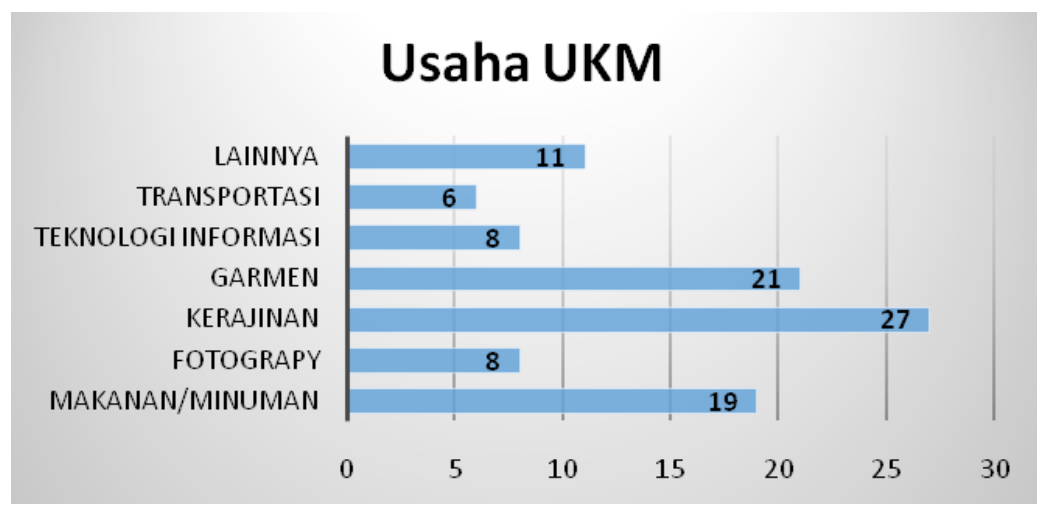

Sumber: Data Primer Diolah 
Diagram sebagaimana tersebut diatas menunjukkan bahwa UKM yang menjadi objek penelitian sebanyak 100, dimana dari 100 UKM tersebut terdistribusi kedalam berbagai industri (bidang usaha), antara lain: (1) kerajinan sebanyak 27 UKM; (2) garmen sebanyak 21 UKM; (3) makanan \& minuman sebanyak 19 UKM; (4) teknologi informasi sebanyak 8 UKM; (5) fotografy sebanyak 8 UKM; (6) transportasi sebanyak 6 UKM; dan (7) UKM yang bergerak dibidang lainnya sebanyak 11 UKM.

\section{Penggunaan Teknologi Informasi}

Pemanfaatan teknologi informasi dalam mendukung penyelesaian pekerjaan nampaknya bukan menjadi barang baru, meskipun tidak semua UKM yang disurvey telah memanfaatkan teknologi informasi. Hasil survey terhadap 100 UKM di Kota Semarang menunjukkan bahwa sebanyak 80 UKM telah menggunakan komputerdalam membantu penyelesaian pekerjaan, sedang sisanya yaitu sebanyak 20 UKM belum menggunakan komputer untuk membantu penyelesaian pekerjaan.

Terdapat berbagai alasan UKM menggunakan komputer maupun tidak menggunakan komputer. Tabel berikut ini menjelaskan proporsi dan alasan UKM yang menggunakan komputer dan tidak menggunakan komputer dalam mendukung penyelesaian pekerjaan.

Tabel 2. UKM Pemakai/Tidak Pemakai Komputer

\begin{tabular}{lcc}
\hline \multicolumn{1}{c}{$\begin{array}{c}\text { Alasan Memakai/Tidak Memakai } \\
\text { Komputer }\end{array}$} & \multicolumn{2}{c}{ Jumlah UKM } \\
\cline { 2 - 3 } Membuat Laporan Keuangan & Pemakai & Tidak Pemakai \\
\hline Membuat Lapotan Kerja & 10 & \\
\hline Mengakses Internet & 35 & \\
\hline Surat-Menyurat & 10 & \\
\hline Keperluan Lainnya & 15 & 9 \\
\hline Tidak Membutuhkan & & 6 \\
\hline Harga Mahal & & 6 \\
\hline Tidak Familier & & \\
\hline
\end{tabular}

Sumber: Data Primer Diolah

Tabel sebagaimana tersebut diatas menunjukkan bahwa terbesar UKM menggunakan komputer untuk akses internet. Dari 35 
UKM yang menggunakan komputer untuk akses internet, umumnya digunakan untuk mencari informasi terkait bisnis usahannya, memasarkan produknya, mencari relasi bisnis, serta mencari desain baru untuk dikembangkan terkait dengan produknya.

Sedang, UKM yang menggunakan komputer untuk menyusun laporan keuangan, laporan kinerja, dan surat-menyurat masing-masing hanya 10 UKM. Fakta ini menunjukkan bahwa sebagian besar UKM masih belum menyusun laporan keuangan, karena sesuai dengan aturan perpajakan UKM-UKM tersebut belum wajib menyusun laporan keuangan, melainkan maksimal sampai pada kewajiban menyusun norma hitung, dan sebagian ketika menyusun laporan keuangan masih bersifat manual.

Jumlah UKM yang tidak menggunakan komputer porsinya relatif kecil. Alasan mereka tidak menggunakan komputer adalah tidak membutuhkan karena jenis pekerjaanya tidak urgen menggunakan komputer, merasa bahwa harga komputer masih mahal, dan tidak familier terhadap komputer, masing masing 9 UKM, 4 UKM, dan 6 UKM.

Menurut hasil survey, hampir semua UKM (100 UKM) yang menggunakan teknologi informasi digynakan untuk mendukung pekerjaanya. Bentuk pemanfaatan teknologi informasi untuk mendukung pekerjaan adalah mulai dari berupa website, blog, sampai hanya sekedar telpon dan SMS. Adapun gambaran bentuk pemanfaatan teknologi informasi untuk mendukung pekerjaan UKM dijelaskan dalam diagram berikut ini:

Gambar 2. Bentuk Pemanfaatan IT Oleh UKM

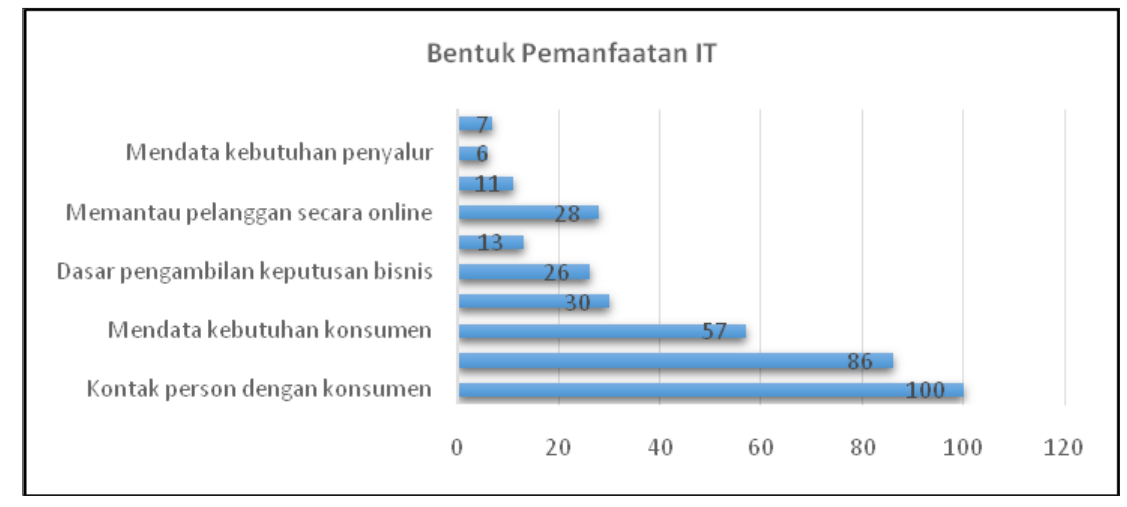

Sumber: Data Primer Diolah 
Gambar tersebut diatas menunjukkan pemanfaatan teknologi informasi oleh para UKM dalam berbagai bentuk kepentingan. Hasil survey dari 100 responden menunjukkan bahwa semua UKM yang menjadi responden telah menggunakan teknologi informasi berupa hand phonyaitu untuk kontak person dengan konsumen, menggunakan promosi sebanyak 86 UKM baik berupa telpon maupun komputer, mendata kebutuhan konsumen sebanyak 57 UKM. Sementara, sebanyak 28 UKM telah melakukan pemantauan pelanggan dengan berbasis online, dan sebanyak 26 UKM menggunakan teknologi informasi untuk membantu pengambilan keputusan.

Mencermati hasil penelitian inin sangat menarik, karena UKM meskipun tergolong kecil mereka telah banyak menggunakan teknologi informasi untuk membantu mengembangkan bisnis.

Jika dilihat dari bentuk teknologi informasi yang digunakan atau media yang digunakan dalam berkomunikasi ternayata banyak variannya. Gambar berikut ini menjelaskan hasil survey tentang media berbasis teknologi informasi yang digunakan untuk komunikasi, yaitu:

Gambar 3. Bentuk Media yang Digunakan UKM

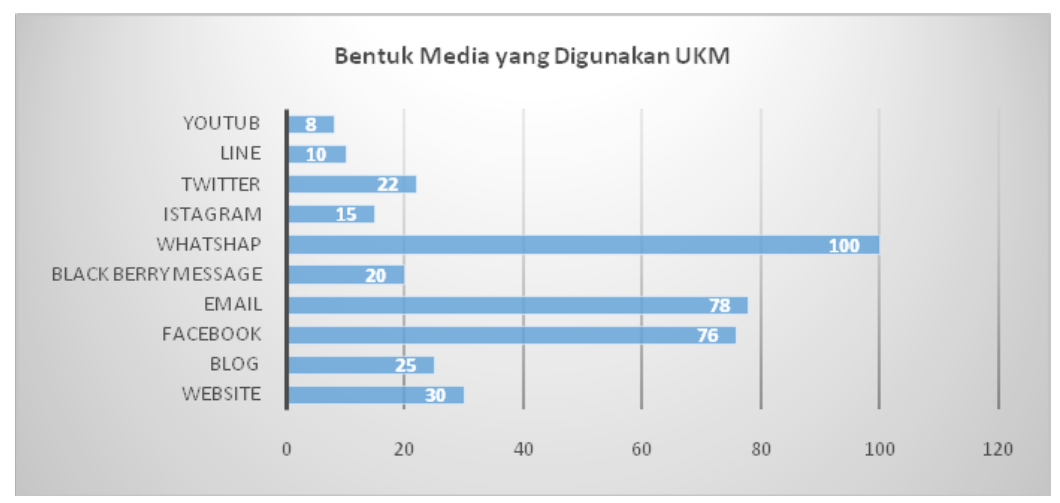

Sumber: Data Primer Diolah

Gambar diagram tersebut diatas menunjukkan bahwa semua pelaku UKM sudah menggunakan teknologi informasi dengan berbagai bentukdalam berkomunikasi. Paling tidak, pelaku UKM menggunakan alat komunikasi telpon selluler baik dengan SMS, whatshap, dan telpon terhadap para relasinya. Terdapat 34 UKM sudah menggunakan E-mail, dan facebook untuk media pemasaran 
dan media komunikasi bisnis. Bahkan, sudah terdapat pelaku UKM yang telah menggunakan website dan blog untuk meningkatkan pemasaran dengan e-marketing.

\section{Manfaat Penggunaan Teknologi Informasi Terhadap Penjualan}

Penggunaan teknik informasi oleh UKM banyak memberikan manfaat. Bukan hanya sekedar memudahkan pelaku UKM melakukan komunikasi terhadap para relasinya, namun pemanfaatan teknologi informasi juga menekan biaya komunikasi dan promosi.

Menurut hasil survey terhadap responden, secara ekonomis sesungguhnya besar sekali manfaat yang dapat dinikmati para pelaku UKM dengan memanfaatkan teknologi informasi. Terlebih, dalam kontek supporting pemasaran, bahwa UKM dapat memanfaatkan untuk meningkatkan market share serta menurunkan biaya promosi dan advertensi. Menurut responden, pemanfaatan teknologi informasi bermanfaat:

a. Meningkatkan market share dengan memanfaatkan e-marketing

b. Menurunkan biaya pemasaran, karena mengurangi infrastruktur pemasaran, seperti:cost labour, cost advertensi, cost display, dan biaya lain terkait

c. Mempercepat jaringan, serta analisis pasar dengan memanfaatkan website dan informasi pemasaran lain di internet

d. Kecepatan dan keakutaran informasi terhadap pelanggan dapat diandalkan

e. Survey kebutuhan pelanggan (konsumen) dapat dilakukan dengan murah dan mudah

f. Mengurangi biaya order dan revisi order jika terjadi kesalahan

Menurut hasil survey juga menunjukkan bahwa pemanfaatan teknologi informasi oleh para pelaku UKM ternyata mampu meningkatkan tingkat penjualan, karena e-commerce memiliki ruang besar tanpa batas, serta terjadinya efisiensi yang dapat menurunkan harga pokok penjualan(cost of good sold). Adapun secara rinci hasil 
survey tentang manfaat teknologi informasi dijelaskan dalam gambar berikut ini:

Gambar 4. Pemanfaatan IT Untuk Peningkatan Penjualan

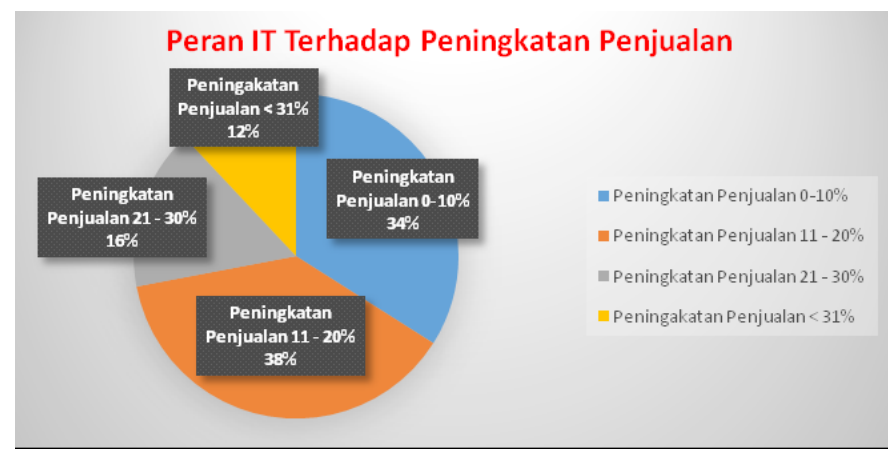

Sumber: Data Primer Diolah

Diagram tersebut diatas menjelaskan bahwa hasil survey terhadap responden (100 UKM) berpendapat penggunaan teknologi informasi memiliki peran besar dan mendorong tingkat penjuaan UKM. 38 \% dari 100 resnponden menyatakan bahwa penggunaan teknik informasi mampu membantu meningkatkan penjualan UKM sebesar $11 \%$ s/d 20\%, sebanyak $34 \%$ dari 100 responden menyatakan penggunaan teknologi informasi mampu mendorong peningkatan penjualan sebesar $0 \mathrm{~s} / \mathrm{d} 10 \%$. Disamping itu, 15\% dari 100 responden juga menyatakan bahwa penggunaan teknologi informasi mampu mebantu menaikkan penjualan $21 \% \mathrm{~b} \mathrm{~s} / \mathrm{d} 30$. Menariknya, terdapat $12 \%$ dari 100 responden yang menyatakan bahwa penggunaan teknologi informasi mampu meningkatkan tingkat penjualan UKM lebih dari $30 \%$.

Mencermati hasil penelitian tersebut, pemanfaatan teknologi informasi oleh UKM patut didorong. Mengingat, teknologi informasi memiliki muatan strategis untuk membantu mempromosikan, memasarkan, penyampaian order, survey konsumen, penjualan dan pembelian, serta media transaksi yang sangat efektif. Kemajuan e-commerce ditengah masyarakat adalah bukti riil bahwa dapat dijadikan strategi alternatif pemasaran UKM dari pola tradisional yang membutuhkan investasi besar. 


\section{Simpulan}

Fakta bahwa perkembangan teknologi informasi tidak dapat dihindari, karena itu UKM sebagai unit bisnis terbesar di Indonesia harus mampu mengadopsi untuk kepentingannya. UKM harus siap melakukan adopsi teknologi informasi tersebut untuk menciptakan competitive advantage, seperti lewat e-commerce atau e-marketing. Menurut hasil survey terhadap 100 pelaku UKM dapat disimpulkan bahwa hampir semua responden (UKM) telah menggunakan teknologi informasi dengan bentuk sesuai kebutuhan, fisibilitas, dan kemampuannya. Pemanfaatan teknologi informasi (telpon selluler dan komputer) dijadikan media komunuikasi, yaitu dalam bentuk: whashap, SMS, website, twitter, blog, intagram, dan bentuk lainnya. Hasil survey juga menunjukkan bahwa penggunaan teknologi informasi dapat digunakan untuk mendongkrak pemasaran dan penjualan, karena adanya e-marketing atau e-commerce yang dilakukan oleh pelakun UKM. 


\section{DAFTAR PUSTAKA}

Apulu, I., Latham, A. 2011. Driver for Information and Communication Technology Adoption: A Case Study of Nigerian Small and Medium Sized Enterprises. International Journal of Business and Management, Vol. 6, No. 5, May

Awad, Elias M. 2004. Electronic commerce: From vision to fulfillment (2nd ed.). Boston: Pearson/Prentice Hall.

Ghobakhloo, M., Sabouri, M.S., Hong, T.S., Zulkifli, N., 2011. Information Technology Adoption in Small and Mediumsized Enterprises; An appraisal of two literature. Interdisciplinary Journal of Research in Business, 1 (7), pp. 53- 80.

Buhalis, D. e 2003, Airlines: Strategic and Tactical Use of ICTs in the Airlines Industry. Information and Management, 41, 805-825.

Hasyim, J. 2007, Information Technology Adption Among SME Owners in Malaysia. International Journal of Business and Information, Vol.2, No. 2, Desember.

Hawk, S. A. 2004. Comparison of B2C e-commerce in Developing Countries. Electronic Commerce Research. 4, 181-199, 2004.

Hengst, M., Sol, H.G. 2011. The Impact of Information and Communication Technology on Interorganizational Coordination: Guidelines from Theory. Informing Science, Special Series on Information Exchange in Electronic Markets, , 2001.

Khristiyanto, Whenny, 2012, Penggunaan Teknologi Informasi di Usaha Kecil dan Menengah (Studi Pada Usaha Kecil Menengah di Wilayah Gedong Meneng), Seminar Hasil-Hasil Penelitian dan Pengabdian Kepada Masyarakat- Dies Natalis FISIP Unila Tahun

Kuzma, J., Bell, V., Logue, C., 2014. A study of the use of social media marketing in the football industry. Journal of Emerging Computing and Information Sciences, 5 (10), pp. 728-738. 
Miller, R., Lammas, N., 2009. Social Media and its Implication for Viral Marketing. Asia Pacific Public Relation Journal, vol 11, pp. 1-9.

Priambada Swanta. 2015. Pekanfaatan Media Sosial pada Usaha Kecil dan Menengah, Seminar Nasional Sistem Informasi Indonesia

Paul, J. 2002. Narrowing the Digital Devide: Initiatives Undertaken by the Association of South-East Asia Nation (ASEAN). Program: Electronic Library and Information Systems, 36(1), 13-22,.

Roger, E.M. 1995. Diffusion of Innovation (4th Edition). New York: The Free Press.

Wahid, F., Iswari, L. 2007. Adopsi Teknologi Informasi Oleh Usaha Kecil dan Menengah Di Indonesia. Seminar Nasional Aplikasi Teknologi Informasi (SNATI), ISSN: 1907-5022, Yogyakarta, 2007.

Wood, C.M. 2004. Marketing and e-Commerce as tools of Development in the Asia- Pasific: A Dual Path. International Marketing Review, 21(3), 301-320,

Zhao, Jensen J. 2003. Web design and development for e-business. Upper Saddle River, NJ: Prentice Hall.

Zhao, Jensen J., Whitesel, Joel A., Alexander, Melody W., et al. 2004. The quality of Fortune 500 B2C e-commerce Web sites: An experiential assessment by online shoppers. Issues in information systems, 5 (1), 359-365. 